\title{
Glucose Regulation of Cephamycin Biosynthesis in Streptomyces lactamdurans is Exerted on the Formation of $\alpha$-Aminoadipyl-cysteinyl-valine and Deacetoxycephalosporin C Synthase
}

\author{
By JESÚS CORTÉS, PALOMA LIRAS, JOSÉ M. CASTRO AND \\ JUAN F. MARTÍN* \\ Departamento de Microbiología, Facultad de Biologia, Universidad de León, León, Spain
}

(Received 30 April 1985; revised 1 October 1985)

\begin{abstract}
Glucose exerted a concentration-dependent negative regulation on the biosynthesis of cephamycin C by Streptomyces lactamdurans. Formation of the cephamycin precursor $\delta(\alpha-$ aminoadipyl)-cysteinyl-valine was greatly decreased by excess glucose. The ring-expanding enzyme deacetoxycephalosporin $\mathrm{C}$ synthase was strongly repressed by glucose in vivo. Isopenicillin $\mathrm{N}$ synthase (cyclase) and isopenicillin $\mathrm{N}$ epimerase were not repressed by glucose. However, the activity of isopenicillin $\mathrm{N}$ synthase was inhibited in vitro by glucose 6-phosphate, and the activity of deacetoxycephalosporin $C$ synthase was inhibited by inorganic phosphate, glucose 6-phosphate, fructose 2,6-diphosphate and fructose 1,6-diphosphate. The intracellular cAMP content decreased as growth proceeded and remained lower in glucose-supplemented cells than in control cultures. cAMP did not seem to be involved in glucose control of cephamycin biosynthesis.
\end{abstract}

\section{INTRODUCTION}

Carbon catabolite regulation is a general mechanism that controls the biosynthesis of antibiotics belonging to different biosynthetic groups (Martin \& Demain, 1980). In some cases, glucose has been found to repress an enzyme of the biosynthetic pathway leading to the antibiotic. Moreover, glucose derivatives formed during transport or glycolysis may inhibit the activity of specific enzymes involved in antibiotic biosynthesis.

The biosynthetic pathways of $\beta$-lactam antibiotics are well understood, but only recently have specific enzymic steps been studied (Hollander et al., 1984; Pang et al., 1984; Ramos et al., 1985). The biosynthesis of cephamycin in Streptomyces proceeds through the same general pathway as that of cephalosporin $C$ in fungi. The tripeptide $\delta(\alpha$-aminoadipyl)-cysteinyl-valine (ACV) is formed by condensation of the component amino acids and then cyclized by the enzyme isopenicillin $\mathrm{N}$ synthase (cyclase). The isopenicillin $\mathrm{N}$ formed is isomerized to penicillin $\mathrm{N}$ by the isopenicillin $\mathrm{N}$ epimerase, and finally the thiazolidine ring of penicillin $\mathrm{N}$ is expanded to a six-membered dihydrotiazine ring by the deacetoxycephalosporin C synthase (Martín \& Liras, 1985) (Fig. 1). ACV formation, isopenicillin $\mathrm{N}$ synthase, isopenicillin $\mathrm{N}$ epimerase and deacetoxycephalosporin C synthase have been characterized in Streptomyces clavuligerus (Jensen et al., 1982, 1983, 1985) and Streptomyces lactamdurans (Castro et al., 1985).

High glucose levels in the medium produced an in vivo accumulation of the penicillin $\mathbf{N}$ intermediate in the cephalosporin C biosynthetic pathway in Acremonium chrysogenum (Zanca \& Martín, 1983), due to repression of the deacetoxycephalosporin C synthase (Behmer \& Demain, 1983). The effect of glucose on penicillin $\mathrm{G}$ formation by Penicillium chrysogenum is due

Abbreviation: ACV, $\delta$-L-( $\alpha$-aminoadipyl)-L-cysteinyl-D-valine. 


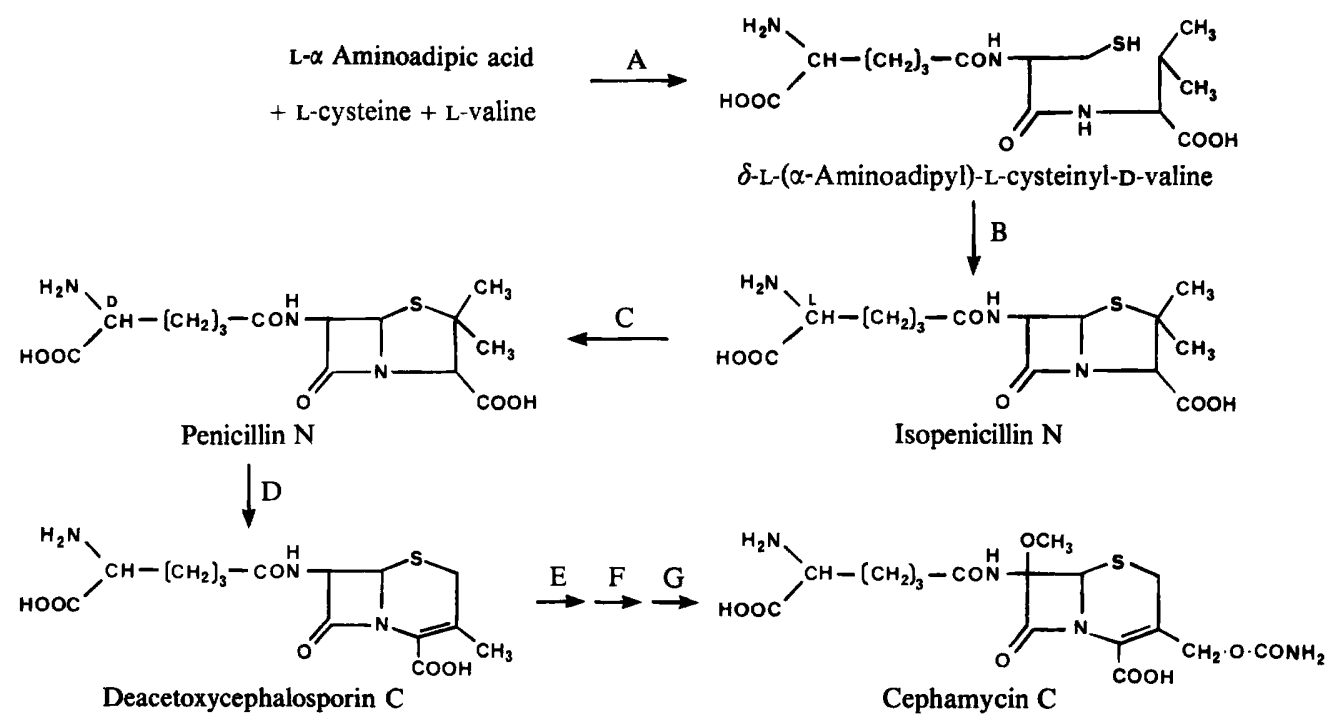

Fig. 1. Biosynthetic pathway of cephamycin C. A, Tripeptide (ACV) synthase; B, isopenicillin N synthase (cyclase); $C$, isopenicillin $\mathrm{N}$ epimerase; $\mathrm{D}$, deacetoxycephalosporin $\mathrm{C}$ synthase (expandase); $\mathrm{E}, \mathrm{F}, \mathrm{G}$, 'late' enzymes.

to a repression of penicillin-synthesizing enzymes (Revilla et al., 1984) and, in particular, of the ACV-forming enzyme system (Martín et al., 1982) and of the isopenicillin N synthase.

Glycerol regulation of cephamycin production has been reported in $S$. clavuligerus (Aharonowitz \& Demain, 1978; Romero et al., 1984) but the enzymes affected by carbon catabolite regulation have not been studied. To establish the mechanism of glucose regulation of $\beta$-lactam biosynthesis in actinomycetes, we have studied the effect of glucose on the formation of ACV, and on the activities of isopenicillin $\mathbf{N}$ synthase, isopenicillin $\mathbf{N}$ epimerase and deacetoxycephalosporin $\mathrm{C}$ synthase in $S$. lactamdurans.

\section{METHODS}

Micro-organisms and culture conditions. S. lactamdurans NRRL 3802 var. JC1843, a strain with improved cephamycin production, was used (Castro et al., 1985). Culture conditions and preparation of resting cell systems were as described by Cortés et al. (1984).

Antibiotic assays. Penicillin N, cephamycin C and deacetoxycephalosporin C were routinely measured by bioassay using Escherichia coli Ess 22-35 as the test strain (Castro et al., 1985). Isopenicillin $\mathrm{N}$ was measured by bioassay against Micrococcus luteus ATCC 9341, a cephamycin-insensitive strain (Castro et al., 1985). The different antibiotics were identified by HPLC, using a Varian 5000 chromatograph with a Micro-Pak mCH10 column, as described previously (Romero et al., 1984). Antibiotic titres are given as $\mu \mathrm{g}$ cephamycin $\mathrm{C}$.

Enzyme extracts. Partially purified cell-free extracts for assays of isopenicillin $\mathrm{N}$ synthase, isopenicillin $\mathrm{N}$ epimerase and deacetoxycephalosporin $\mathrm{C}$ synthase were prepared by sonicating cells grown for $72 \mathrm{~h}$ (Cortés et al., 1984). Ultracentrifuged extracts ( $100000 \mathrm{~g}$ for $2 \mathrm{~h}$, Beckman LB-70) were treated with $0.2 \%$ protamine sulphate, and the clear supernatant was precipitated with ammonium sulphate (30-50\% saturation for isopenicillin $\mathrm{N}$ epimerase and 50-80\% saturation for isopenicillin $\mathrm{N}$ synthase and deacetoxycephalosporin $\mathrm{C}$ synthase).

Enzyme assays. Isopenicillin $\mathrm{N}$ synthase, isopenicillin $\mathrm{N}$ epimerase and deacetoxycephalosporin $\mathrm{C}$ synthase were assayed in reaction mixtures prepared as described previously (Cortés et al., 1984; Castro et al., 1985), supplemented with $1 \mathrm{~mm}$-phenylmethylsulphonyl fluoride (PMSF). Specific enzyme activities are given as nkat (g protein) $)^{-1}$.

Intracellular glucose 6-phosphate content. Glucose 6-phosphate was extracted from washed mycelium with $10 \%$ $(\mathrm{w} / \mathrm{v})$ TCA. The protein precipitate was discarded and the TCA present in the supernatant was removed by extracting twice with an equal volume of diethyl ether. Residual ether in the aqueous fraction was removed under vacuum. The glucose 6-phosphate content in the sample was determined by measuring the reduction of NADP by 
glucose-6-phosphate dehydrogenase at $A_{340} ; 1 \mu \mathrm{mol}$ glucose 6-phosphate produced an increase of 6.02 (Horecker \& Wood, 1957). The reaction mixture contained, in a final volume of $1 \mathrm{ml}: \mathrm{MgCl}_{2}, 10 \mathrm{mM}$; NADP, $0.13 \mathrm{mM}$; glucose-6-phosphate dehydrogenase, 1.25 units; Tris/HCl buffer $\mathrm{pH} 7 \cdot 5,15 \mathrm{~mm}$.

cAMP determination. Mycelium was extracted with $10 \%$ TCA as indicated above, and cAMP was determined by the competition between $\mathrm{CAMP}$ in the sample and exogenous $\left[8-{ }^{-} \mathrm{H}\right] \mathrm{cAMP}$ for the cAMP-binding protein, using a cAMP assay kit (Amersham) according to the manufacturer's instructions. The bound radioactivity was measured in a Philips 4700 liquid scintillation counter. The kit was calibrated with pure cAMP (Sigma).

Determination of $A C V$ and glutathione. ACV and glutathione were extracted with $7.5 \%(\mathrm{w} / \mathrm{v}) \mathrm{TCA}$ from samples of mycelium (approximately $250 \mathrm{mg}$ dry weight) taken at various times of culture, and purified as described by Loder \& Abraham (1971). After oxidation with performic acid, the sulphonated peptides were derivatized with $o$ phthaldialdehyde and separated in a Varian 5000 HPLC chromatograph equipped with a Micro-Pak mCH10 reverse-phase column using a mixture of $10 \mathrm{mM}$-phosphate buffer, $\mathrm{pH} 7$, and methanol $(9: 10, \mathrm{v} / \mathrm{v})$ as solvent. The intracellular content of these tripeptides was quantified by using pure ACV or glutathione as standards (Cortés $e t$ al., 1984).

Determination of glucose, protein and inorganic phosphate. Glucose was determined by the glucose oxidase method, protein by the Lowry method and inorganic phosphate by the method of Fiske and Subbarow as described by Leloir \& Cardini (1957).

Chemicals. Glucose 6-phosphate, fructose 1,6-diphosphate, fructose 2,6-diphosphate and glucose-6-phosphate dehydrogenase (type XII from Torula) were obtained from Sigma. The isopenicillin N and ACV were a gift from Dr P. Van Dijck (Gist Brocades, Delft, The Netherlands) and penicillin N was kindly supplied by Dr H. H. Peter (Ciba Geigy, Basel, Switzerland). All other chemicals were of reagent quality.

\section{RESULTS}

Effect of glucose and phosphate on cephamycin C production in batch cultures. Maltose, glucose (at low concentrations) and galactose supported good antibiotic production by $S$. lactamdurans when added to nutrient broth/yeast extract (NY) base medium, whereas glycerol, lactose, sucrose and starch did not support cephamycin production.

$S$. lactamdurans grew similarly in NYG medium supplemented with $165 \mathrm{~mm}$ (high) or $55 \mathrm{~mm}$ (low) glucose, probably because in both cases growth was limited by phosphate. Glucose was exhausted from control cultures (containing $55 \mathrm{~mm}$-glucose) at $72 \mathrm{~h}$ of incubation, but remained at high concentration throughout the fermentation in high glucose cultures (Fig. 2). The pH of the culture medium increased slightly during the fermentation but it was not modified as a result of addition of high concentrations of glucose.

The biosynthesis of cephamycin $\mathrm{C}$, however, was greatly dependent on the glucose concentration $(27 \cdot 5,55,110$ or $165 \mathrm{mM})$ of the medium. Production of antibiotic in control cells grown in $55 \mathrm{~mm}$-glucose started at about $48 \mathrm{~h}$ of fermentation (Fig. $2 \mathrm{~b}$ ). The onset of antibiotic production was delayed as the glucose concentration was increased from $27.5 \mathrm{~mm}$ to $110 \mathrm{mM}$. No antibiotic was detected in batch cultures supplemented with $165 \mathrm{~mm}$-glucose. Addition of inorganic phosphate $(25-50 \mathrm{mM})$ to the cultures containing $55 \mathrm{~mm}$-glucose stimulated growth and produced an early onset of cephamycin $\mathrm{C}$ biosynthesis without inhibiting the production of the antibiotic. The same results were obtained in three different experiments.

The antibiotic formed was insensitive to penicillinase (as are cephalosporin and cephamycin) in all cases. No accumulation of any penicillinase-sensitive antibiotic (e.g. isopenicillin $\mathrm{N}$ or penicillin $\mathrm{N}$ ) as a result of the inhibition of cephamycin $\mathrm{C}$ biosynthesis by glucose was observed.

Control by glucose and its phosphorylated derivatives of cephamycin C biosynthesis by resting cells. To study the glucose effect under controlled conditions avoiding the indirect effect of growth, resting cells of $S$. lactamdurans in MOPS buffer were prepared from cells grown in NYG medium supplemented with high or low glucose (Fig. 3). Glucose produced a concentrationdependent reduction of cephamycin biosynthesis. Cells grown in high glucose showed a delayed onset of cephamycin $\mathrm{C}$ production; however, when cephamycin synthesis commenced it proceeded at about the same rate as in control cells. Final levels of cephamycin were lower than half those produced by cells grown in low glucose (Fig. 3). When the resting cells were supplemented with an additional $165 \mathrm{~mm}$-glucose, formation of antibiotic was still further reduced (see Discussion). 


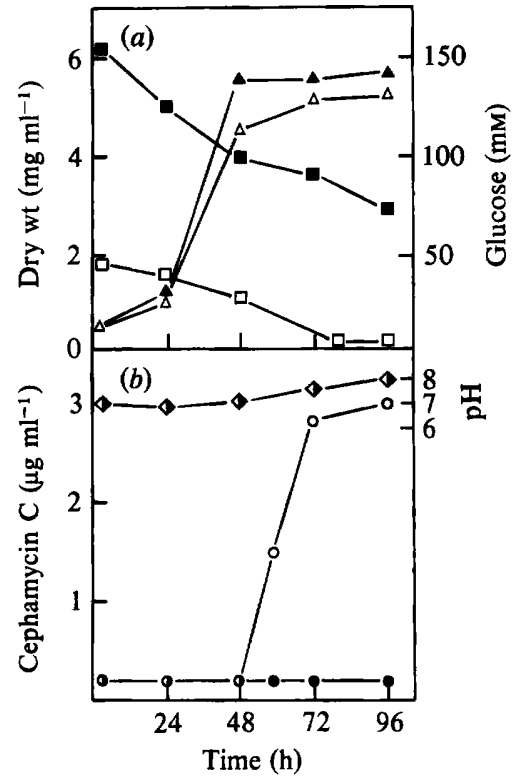

Fig. 2.

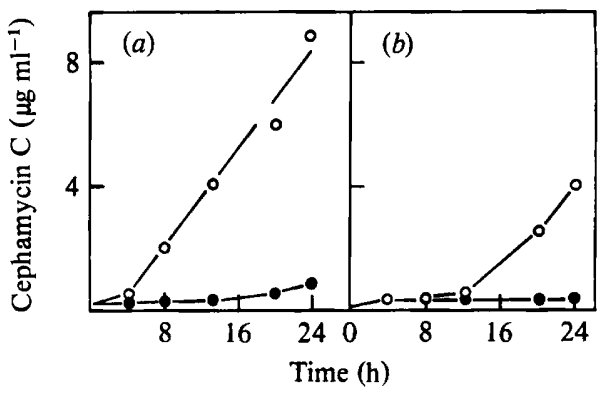

Fig. 3

Fig. 2. Effect of glucose on cephamycin biosynthesis by batch cultures of $S$. lactamdurans. (a) Growth in NYG medium $(\triangle, \Delta)$ and residual sugar in cultures $(\square, \square)$ with $55(\triangle, \square)$ or $165(\Delta, \square)$ mM-glucose. (b) Cephamycin produced in medium with $55(\mathrm{O})$ or $165(\mathrm{O}) \mathrm{mM}$-glucose, and $\mathrm{pH}$ in glucosesupplemented or unsupplemented cultures $(\nabla)$. Results are from a representative experiment of four determinations.

Fig. 3. Effect of glucose on the biosynthesis of cephamycin $\mathrm{C}$ by resting cells of $S$. lactamdurans. Resting cells were prepared from cultures grown in $(a) 55 \mathrm{mM}$-glucose or $(b) 165 \mathrm{mM}$-glucose. In each case, washed resting cells were supplemented $(O)$ or not $(O)$ with additional $165 \mathrm{~mm}$-glucose. Note that the higher production of cephamycin per $\mathrm{ml}$ by resting cells is due to the fact that cells were concentrated four-fold, with respect to the cell density of the NYG culture. Results are from a representative experiment of five determinations.

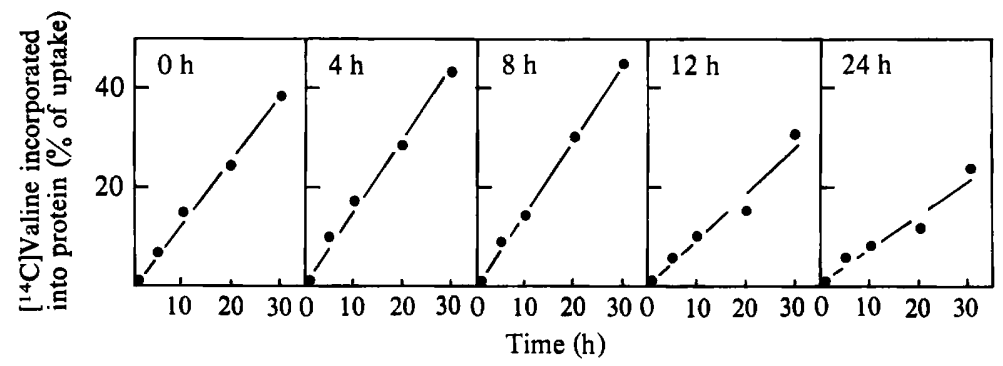

Fig. 4. Kinetics of protein synthesis by resting cells of $S$. lactamdurans at $0,4,8,12$ and $24 \mathrm{~h}$. Protein synthesis is expressed as the percentage of $\left[{ }^{14} \mathrm{C}\right]$ valine taken up by the cells that was incorporated into protein; results are means of two determinations. Uptake of $\left[{ }^{14} \mathrm{C}\right]$ valine was $60 \%$ of the total radioactivity added to the culture $\left(10^{5}\right.$ c.p.m. ml $\left.{ }^{-1}\right)$, and did not change significantly during the $24 \mathrm{~h}$ of incubation.

To establish if the delayed onset of cephamycin biosynthesis by resting cells obtained from $165 \mathrm{~mm}$-glucose-grown cultures was due to late derepression of cephamycin-forming enzymes, the protein turnover in resting cells was determined (Fig. 4). Protein synthesis was observed in cells suspended in a carbon-, nitrogen- and phosphate-free buffer. That a significant protein synthesis takes place in resting cells suggested that the enzymes involved in cephamycin 


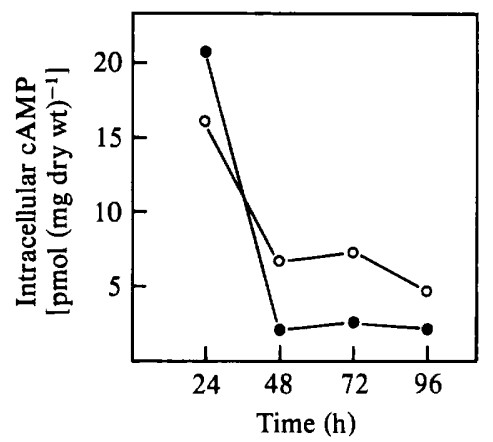

Fig. 5. Intracellular cAMP pool of cells grown in batch cultures with $55(O)$ or $165(O)$ mM-glucose. Results are means of three determinations.

biosynthesis might be repressed in cells grown in high glucose at the time the cells were collected to prepare the resting cell system.

Inorganic phosphate $(10 \mathrm{mM})$, when added either to control or glucose-supplemented resting cells, did not modify the yield of antibiotic. Several phosphorylated derivatives of glucose (5$10 \mathrm{mM}$ ) were studied as possible effectors. Glucose 6-phosphate $(10 \mathrm{mM})$ and 2-deoxyglucose 6phosphate $(5 \mathrm{mM})$ completely blocked cephamycin $C$ production in resting cells. Indeed, these glucose derivatives had a greater regulatory effect than glucose at the same concentration. This trend was consistently observed in four different experiments. The regulatory effect produced in vivo by glucose 6-phosphate may be exerted at the membrane level, since it is not clear whether this compound is taken up in the intact form.

Effect of glucose on intracellular cAMP content. The intracellular cAMP content in $S$. lactamdurans was very high early in the growth phase of the culture when the glucose content of the medium was also high (Fig. 5), but it decreased later, reaching a steady low level after $48 \mathrm{~h}$ incubation. The concentration after $48 \mathrm{~h}$ was two to three times lower in glucose-supplemented cells than in control cultures after $48 \mathrm{~h}$ incubation when the antibiotic was being produced. This pattern does not support the involvement of cAMP in glucose control of cephamycin biosynthesis (see Discussion).

Intracellular ACV and glutathione levels. The pool of ACV was determined in control and glucose-supplemented cells. ACV content in control cells was very high early in the fermentation (24-36 h) just before antibiotic production began, and then decreased rapidly (Fig. 6a). The pool of ACV in cultures supplemented with $165 \mathrm{~mm}$-glucose was about $25 \%$ of that in control cells, suggesting that either the supply of precursor amino acids for ACV synthesis was lower, or the ACV synthase was repressed in cells grown in high glucose concentrations.

The intracellular content of glutathione ( $\gamma$-glutamyl-cysteinyl-glycine), a structural analogue of ACV that is not a precursor of penicillin, was stimulated by addition of a high glucose concentration to the cells (Fig. $6 b$ ). However, glutathione has many other poorly known cellular functions and its level in cells may have little to do with antibiotic production. The pool of glutathione increased considerably between 24 and $48 \mathrm{~h}$ in control and glucose-supplemented cultures and then decreased, but in all cases it was higher in cells grown in high glucose concentrations than in control cultures.

Isopenicillin $N$ synthase, isopenicillin $N$ epimerase and deacetoxycephalosporin $C$ synthase. Both isopenicillin $\mathrm{N}$ synthase and isopenicillin $\mathrm{N}$ epimerase activities of $S$. lactamdurans cells grown in high glucose concentrations were slightly greater than those in control cells, although formation of the isopenicillin $\mathrm{N}$ synthase in glucose-supplemented cells was delayed with respect to control cultures (Fig. 7a,b). Deacetoxycephalosporin $\mathrm{C}$ synthase ('expandase') activity increased steadily throughout the fermentation in control cells. In cells grown in high glucose concentrations, the enzyme was not detected before $48 \mathrm{~h}$ of fermentation, a delay of 


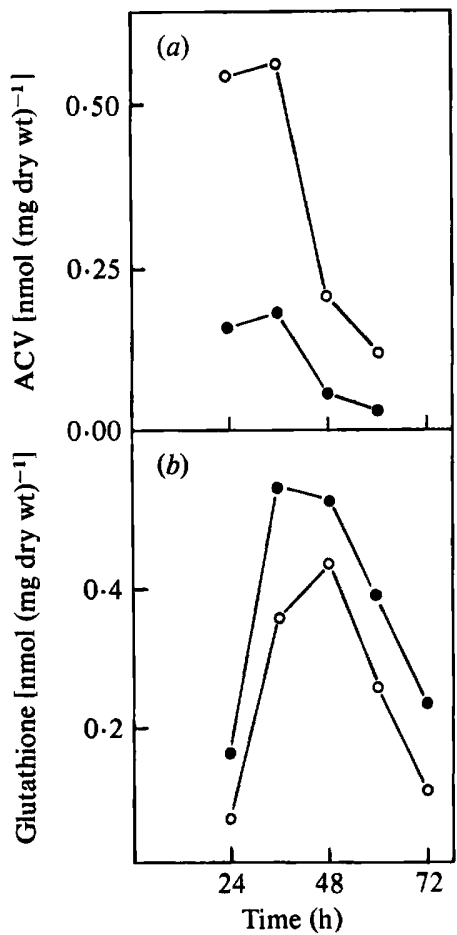

Fig. 6

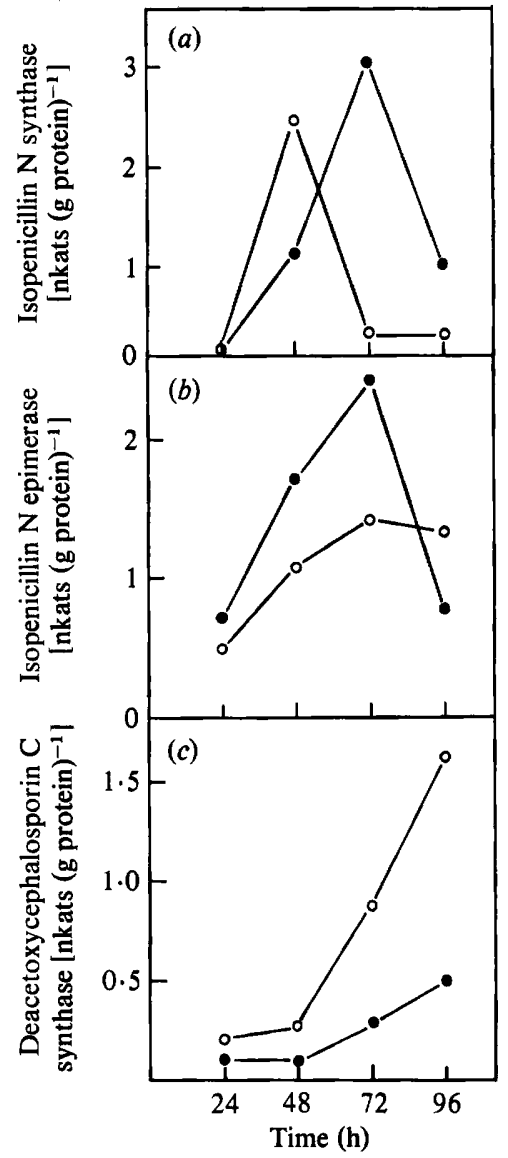

Fig. 7

Fig. 6. Intracellular content of $(a) \mathrm{ACV}$ and $(b)$ glutathione in cells grown in batch cultures with $55(\mathrm{O})$ or $165(0) \mathrm{mm}$-glucose. Results are means of three determinations.

Fig. 7. Time course of the specific activities of $(a)$ isopenicillin $\mathrm{N}$ synthase, $(b)$ isopenicillin $\mathrm{N}$ epimerase and $(c)$ deacetoxycephalosporin $C$ synthase of cells grown in $55(O)$ or $165(O)$ mM-glucose. Results are means of three determinations.

more than $24 \mathrm{~h}$ with respect to control cells; but later a low level of activity was observed (Fig. $7 c$ ). These results suggest that the expandase activity was strongly repressed and/or inhibited by glucose (see Discussion).

Inhibition of cephamycin biosynthetic enzymes by glycolytic intermediates and inorganic phosphate. Several glycolytic intermediates, ATP and phosphate were tested as possible effectors on the in vitro activities of isopenicillin $\mathrm{N}$ synthase, isopenicillin $\mathrm{N}$ epimerase and deacetoxycephalosporin $\mathrm{C}$ synthase (Table 1). Glucose 6-phosphate (1 mM) produced a $53 \%$ inhibition of the activity of deacetoxycephalosporin $C$ synthase and a strong inhibition ( $83 \%$ of isopenicillin $\mathrm{N}$ synthase. Fructose 1,6-diphosphate also inhibited deacetoxycephalosporin $\mathrm{C}$ synthase $(46 \%)$ and fructose 2,6-diphosphate produced a similar effect. None of the other glycolytic intermediates tested had a significant effect on cyclase and expandase. Isopenicillin $\mathbf{N}$ epimerase was partially inhibited only by fructose 1,6-diphosphate and 2-phosphoglycerate.

Inorganic phosphate $(1 \mathrm{mM})$ inhibited deacetoxycephalosporin $\mathrm{C}$ synthase but not isopenicillin $\mathbf{N}$ epimerase or isopenicillin $\mathbf{N}$ synthase. Inorganic phosphate and the sugar phosphates exerted a concentration-dependent inhibition of deacetoxycephalosporin $\mathrm{C}$ synthase (Fig. 8). 


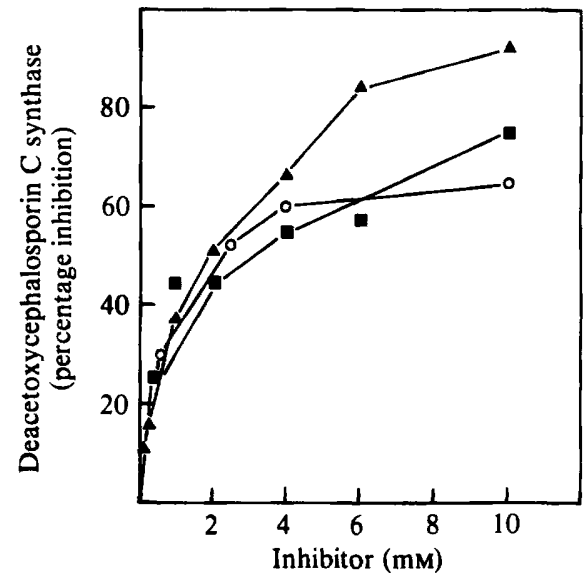

Fig. 8
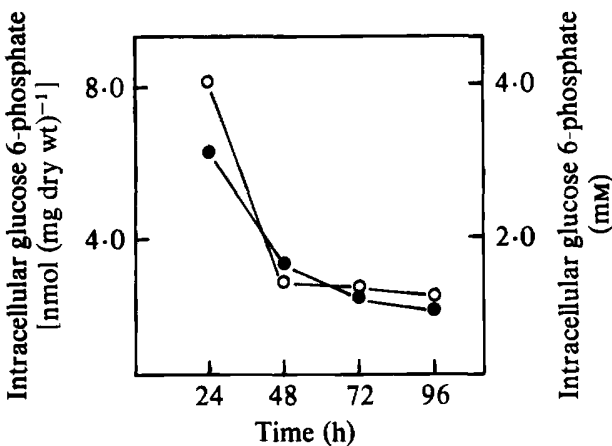

Fig. 9

Fig. 8. Effect of increasing concentrations of glucose 6-phosphate $(\Delta)$, fructose 1,6-diphosphate $(\square)$ and inorganic phosphate $(O)$ on the activity of deacetoxycephalosporin $C$ synthase. Results are means of two determinations. The activity of the control (uninhibited) reaction was 0.47 nkat (g protein) ${ }^{-1}$.

Fig. 9. Changes in the intracellular content of glucose 6-phosphate during batch culture in medium containing $55(\mathrm{O})$ or $165(\mathrm{O}) \mathrm{mm}$-glucose. Results are means of three determinations.

Table 1. Effect of glycolytic intermediates, ATP and phosphate on the in vitro activity of isopenicillin $N$ synthase, isopenicillin $N$ epimerase and deacetoxycephalosporin $C$ synthase of

\section{S. lactamdurans}

Enzyme extracts were obtained from $72 \mathrm{~h}$ cultures by sonication and purified as described in Methods. Results are means of three determinations. The values in parentheses are percentages of the control.

\begin{tabular}{|c|c|c|c|}
\hline \multirow[b]{2}{*}{ Addition (1 mM) } & \multicolumn{3}{|c|}{ Specific activity [nkat (g protein $)^{-1}$ ] } \\
\hline & $\begin{array}{l}\text { Isopenicillin } \\
\mathbf{N} \text { synthase }\end{array}$ & $\begin{array}{l}\text { Isopenicillin } \\
\mathrm{N} \text { epimerase }\end{array}$ & $\begin{array}{c}\text { Deacetoxycephalosporin } \\
\text { C synthase }\end{array}$ \\
\hline None & $4 \cdot 27(100)$ & $1 \cdot 17(100)$ & $0 \cdot 26(100)$ \\
\hline Glucose & $4 \cdot 27(100)$ & $1 \cdot 17(100)$ & $0.26(100)$ \\
\hline Glucose 6-phosphate & $0.72(17)$ & $1 \cdot 17(100)$ & $0.12 \quad(47)$ \\
\hline Fructose 6-phosphate & $4 \cdot 27(100)$ & $1.17(100)$ & $0.26(100)$ \\
\hline Fructose 1,6-diphosphate & $4.27(100)$ & $0.78(66)$ & $0.14 \quad(54)$ \\
\hline Fructose 2,6-diphosphate & $4 \cdot 27(100)$ & $1 \cdot 17(100)$ & $0.09 \quad(35)$ \\
\hline 2-Phosphoglycerate & $4 \cdot 27(100)$ & $0.78 \quad(66)$ & $0.26(100)$ \\
\hline 3-Phosphoglycerate & $4 \cdot 27(100)$ & $1 \cdot 17(100)$ & $0.26(100)$ \\
\hline 2,3-Diphosphoglycerate & $4 \cdot 27(100)$ & $1 \cdot 17(100)$ & $0.26(100)$ \\
\hline Phosphoenolpyruvate & $4 \cdot 27(100)$ & $1 \cdot 17(100)$ & $0.26(100)$ \\
\hline Pyruvate & $3.73(87)$ & $1 \cdot 17(100)$ & $0.24 \quad(94)$ \\
\hline Phosphate & $4.27(100)$ & $1 \cdot 17(100)$ & $0.15(60)$ \\
\hline ATP & ND & ND & $0.26(100)$ \\
\hline
\end{tabular}

ND, Not determined.

Inorganic phosphate, glucose 6-phosphate or fructose 1,6-diphosphate, each at $2 \mathrm{~mm}$, produced a $50 \%$ inhibition of deacetoxycephalosporin $\mathrm{C}$ synthase.

The phosphate effect may have been due to the sequestration of $\mathrm{Fe}^{2+}$ ions required for deacetoxycephalosporin $C$ synthase activity. However, no reversal of the phosphate effect by increasing concentrations of $\mathrm{Fe}^{2+}$ was obtained in several experiments. To test if the effect of glucose 6-phosphate was due to the presence of free phosphate released by hydrolysis, both free glucose and inorganic phosphate were determined in the reaction samples containing glucose 
6-phosphate. No hydrolysis of glucose 6-phosphate was detected, indicating that glucose 6-phosphate itself was the inhibitory effector.

Intracellular glucose 6-phosphate content. Since glucose 6-phosphate inhibited at least two enzymes of the cephamycin biosynthetic pathway, its intracellular concentration was determined in cells grown in either high or low glucose concentrations (Fig. 9). Glucose 6phosphate followed a similar pattern to that of cAMP: it was high early in the fermentation and decreased at between 24 and $48 \mathrm{~h}$ of growth. No difference in the intracellular concentration of glucose 6-phosphate per mg dry weight was observed as a result of glucose supplementation. However, if the glucose 6-phosphate concentration was calculated in relation to the approximate volume of the cells, the intracellular concentration was high enough to produce an 'in vivo' inhibition of cyclase and expandase at early times in the fermentation (Fig. 9).

The intracellular volume of $S$. lactamdurans has been estimated as $2.0 \mu \mathrm{l}$ per $\mathrm{mg}$ dry wt, which compares well with the reported values for Streptococcus salivarius $(2 \mu \mathrm{l}$ per $\mathrm{mg}$ dry wt) (Vadeboncoeur \& Trahan, 1982), Zymomonas mobilis $(3.3 \mu \mathrm{l}$ per mg dry wt) (Dimarco \& Romano, 1985) and Streptomyces antibioticus (1.3-1.7 $\mu$ l per mg dry wt) (J. Salas, personal communication).

\section{DISCUSSION}

Glucose exerted a strong negative regulation on cephamycin biosynthesis by $S$. lactamdurans, similar to the repressive effect of glucose on penicillin formation by $P$. chrysogenum (Revilla $e t$ al., 1984), and more intense than the effect of glucose on cephalosporin biosynthesis by $A$. chrysogenum (Zanca \& Martín, 1983; Behmer \& Demain, 1983).

Glucose transport and/or catabolism repressed both ACV formation and the ring expansion catalysed by deacetoxycephalosporin $\mathrm{C}$ synthase until the glucose concentration decreased below a threshold level. Repression of ACV formation by glucose has also been found in $P$. chrysogenum (Martín et al., 1982; G. Revilla \& J. F. Martín, unpublished). Deacetoxycephalosporin $\mathrm{C}$ synthase (expandase) was also sensitive to glucose repression in $A$. chrysogenum (Behmer \& Demain, 1983; Zanca \& Martín, 1983; Heim et al., 1984). On the contrary, the isopenicillin $\mathrm{N}$ synthase and the epimerase of $S$. lactamdurans were not sensitive to repression by glucose (Fig. 7). Similarly, the cyclase of $A$. chrysogenum was less sensitive to carbon catabolite regulation (Heim et al., 1984). In general, it seems that ACV biosynthesis and ring expansion are very sensitive to carbon catabolite regulation.

Nitrogen source repression of cephamycin biosynthesis in $S$. lactamdurans is exerted coordinately on four enzymes of the biosynthetic pathway [tripeptide-forming enzyme(s), cyclase, epimerase and expandase] (Castro et al., 1985). Carbon catabolite regulation of cephamycin formation in this streptomycete does not appear to be exerted coordinately on these enzymes (Figs 6 and 7). Rather, it seems that two of the steps of the biosynthetic pathway (formation of ACV and ring expansion) are particularly sensitive to carbon catabolite regulation. It is interesting that carbon catabolite regulation in $S$. lactamdurans specifically affected the formation of a peptide involved in penicillin biosynthesis, and did not repress the biosynthesis of glutathione (Fig. 6), a tripeptide that is also formed by a non-ribosomal enzyme system probably similar to that responsible for ACV biosynthesis (Fawcett \& Abraham, 1975; López-Nieto et al., 1985).

Glucose also had a drastic effect on cephamycin biosynthesis by resting cells in short-term experiments (Fig. 3), which might be explained, at least in part, by the fact that protein synthesis, and therefore the de novo formation of cephamycin synthases, is intense in resting cells (Fig. 4). Our results suggest that inhibition of the activity of preformed enzymes may also play an important role in glucose control of cephamycin biosynthesis. In effect, the expandase activity was strongly inhibited in vitro by glucose 6-phosphate, fructose 1,6-diphosphate and inorganic phosphate and the cyclase was inhibited by glucose 6-phosphate. Fructose 2,6-diphosphate, which has been described as a regulatory effector of glycolysis in higher cells (Hers et al., 1982), had a significant inhibition effect on expandase but showed no effect on the other two enzymes (Table 1). 
A decreased $\mathrm{O}_{2}$ availability as a result of glucose addition has been suggested by Braña et al. (1983). In our conditions, especially in the resting cells, addition of glucose did not increase growth. Therefore, it seems unlikely that depletion of $\mathrm{O}_{2}$ occurs, although we cannot exclude this possibility.

The role of inorganic phosphate in the control of cephamycin biosynthesis in S. lactamdurans is less intense. Inorganic phosphate, alone or when added to glucose-supplemented fermentations, did not affect total cephamycin biosynthesis in vivo; this effect is different from that observed in $A$. chrysogenum and $P$. chrysogenum (Martin et al., 1982), where inorganic phosphate enhances the regulation exerted by glucose. Lubbe et al. (1984) have suggested that phosphate inhibits the expandase activity of $S$. clavuligerus by sequestering $\mathrm{Fe}^{2+}$ ions required for activity of this enzyme. However, we were unable, in repeated experiments, to reverse the inhibition by phosphate of the expandase of $S$. lactamdurans by addition of high $\mathrm{Fe}^{2+}$ concentrations.

cAMP is involved in carbon catabolite regulation by glucose in enterobacteria (Perlman et al., 1969), but such involvement in other micro-organisms is, so far, not clear. The time-course of intracellular cAMP accumulation during fermentation, which shows a sharp decrease in parallel with glucose depletion (in contrast to the situation in enterobacteria), indicates that carbon catabolite regulation of cephamycin biosynthesis is not mediated by cAMP. These results agree with similar observations made by Vining and coworkers, who also concluded that cAMP was not involved in the onset of streptomycin biosynthesis in Streptomyces griseus (Regan \& Vining, 1978 ) or in carbon catabolite repression of $\beta$-galactosidase in Streptomyces venezuelae (Chatterjee \& Vining, 1981). cAMP in Streptomyces follows the same pattern as intracellular ATP and other nucleotides involved in the control of phosphate-sensitive antibiotic biosynthesis (Martín \& Demain, 1977; Martín et al., 1978), but does not appear to be involved in carbon catabolite regulation of antibiotic production.

This work was supported by a grant of the CAICYT, Madrid. J. Cortes and J. M. Castro acknowledge fellowships from the Ministry of Foreign Affairs, and the PFPI program, Ministry of Education and Science, Madrid, respectively. We are grateful to A. L. Demain, M.I.T. (USA), for critical reading of the manuscript, and to L. Vara and M. P. Puertas for excellent technical assistance.

\section{REFERENCES}

Aharonowitz, Y. \& Demain, A. L. (1978). Carbon catabolite regulation of cephalosporin production in Streptomyces clavuligerus. Antimicrobial Agents and Chemotherapy 14, 159-164.

Behmer, C. J. \& Demain, A. L. (1983). Further studies on carbon catabolite regulation of $\beta$-lactam antibiotic synthesis in Cephalosporium acremonium. Current Microbiology 8, 107-114.

Braña, A. F., Hu, W. S. \& Demain, A. L. (1983). Involvement of aeration in carbon source regulation of cephem antibiotic biosynthesis in Streptomyces clavuligerus. Biotechnology Letters 5, 791-794.

Castro, J. M., Liras, P., Cortés, J. \& Martín, J. F. (1985). Regulation of $\delta(\alpha$-aminoadipyl-cysteinylvaline), isopenicillin $\mathbf{N}$ synthetase, isopenicillin $\mathbf{N}$ isomerase and deacetoxycephalosporin $\mathrm{C}$ synthetase by nitrogen sources in Streptomyces lactamdurans. Applied Microbiology and Biotechnology 21, 32-40.

ChatterJee, S. \& Vining, L. C. (1981). Catabolite repression in Streptomyces venezuelae. Induction of $\beta$-galactosidase, chloramphenicol production and intracellular cyclic adenosine $3^{\prime}$-5'-monophosphate concentrations. Canadian Journal of Microbiology 28, 311-317.
Cortés, J., Liras, P., Castro, J. M., Romero, J. \& MARTín, J. F. (1984). Regulation of the biosynthesis of cephamycin by Streptomyces lactamdurans. Biochemical Society Transactions 12, 863-864.

Dimarco, A. A. \& Romano, A. H. (1985). D-Glucose transport system of Zymomonas mobilis. Applied and Environmental Microbiology 49, 151-157.

FawCETt, P. \& AbRaham, E. P. (1975). $\delta$ ( $\alpha$-aminoadipyl)cysteinylvaline synthetase. Methods in Enzymo$\log y$ 43, 471-473.

Heim, J., Shen, J. Q., Wolfe, S. \& Demain, A. L. (1984). Regulation of isopenicillin $\mathbf{N}$ synthetase and deacetoxycephalosporin $\mathrm{C}$ synthetase by carbon sources during the fermentation of Cephalosporium acremonium. Applied Microbiology and Biotechnology 19, 232-236.

Hers, H. G., Hue, L. \& Van Schaftingen, E. (1982). Fructose 2,6-biphosphate. Trends in Biochemical Sciences 7, 329-331.

Hollander, I. J., Shen, Y. Q., Heim, J., Demain, A. L. \& Wolfe, S. (1984). A pure enzyme catalyzing penicillin biosynthesis. Science 224, 610-612.

HoRECKER, B. L. \& WOOD, W. A. (1957). D-Glucose-6phosphate. Methods in Enzymology 3, 152-154. 
Jensen, S. E., Westlake, D. W. S. \& Wolfe, S. (1982). Cyclization of $\delta(L-\alpha$-aminoadipyl)-L-cysteinyl-Dvaline to penicillin by cell free extracts of Streptomyces clavuligerus. Journal of Antibiotics 35, 483-490.

Jensen, S. E., Westlake, D. W. S. \& Wolfe, S. (1983). Partial purification and characterization of isopenicillin $\mathbf{N}$ epimerase activity from Streptomyces clavuligerus. Canadian Journal of Microbiology 29, 1526-1531.

JenSEN, S. E., Westlake, D. W. S. \& Wolfe, S. (1985). Deacetoxycephalosporin $C$ synthetase and deacetoxycephalosporin $\mathrm{C}$ hydroxylase are two different enzymes in Streptomyces clavuligerus. Journal of Antibiotics 38, 263-265.

Leloir, L. F. \& CARDINI, C. E. (1957). Characterization of phosphorus compounds by acid lability. Methods in Enzymology 3, 840-850.

LODER, P. B. \& ABraham, E. P. (1971). Isolation and nature of intracellular peptides from a cephalosporin C producing Cephalosporium sp. Biochemical Journal 123, $471-476$.

López-Nieto, M. J., Ramos, F. R., Luengo, J. M. \& Martín, J. F. (1985) Characterization of the biosynthesis in vivo of $\alpha$-aminoadipyl-cysteinylvaline in Penicillium chrysogenum. Applied Microbiology and Biotechnology 21, 343-351.

Lubbe, C., Jensen, S. E. \& Demain, A. L. (1984). Prevention of phosphate inhibition of cephalosporin synthetase by ferrous ion. FEMS Microbiology Letters 25, 75-79.

Martín, J. F. \& Demain, A. L. (1977). Effect of exogenous nucleotides on the candicidin fermentation. Canadian Journal of Microbiology 23, 13341339.

Martín, J. F. \& Demain, A. L. (1980). Control of antibiotic biosynthesis. Microbiological Reviews 44, $230-251$.

Martín, J. F. \& LiRas, P. (1985). Biosynthesis of $\beta$ lactam antibiotics: design and construction of overproducing strains. Trends in Biotechnology 3, 3944.

Martín, J. F., Liras, P. \& Demain, A. L. (1978). ATP and adenylate energy charge during phosphatemediated control of antibiotic synthesis. Biochemical and Biophysical Research Communications 83, 822828.
Martín, J. F., Revilla, G., Zanca, D. M. \& LópezNiETo, M. J. (1982). Carbon catabolite regulation of penicillin and cephalosporin biosynthesis. In Trends in Antibiotic Research, pp. 258-268. Edited by $\mathrm{H}$. Umezawa, A. L. Demain, T. Hata \& C. R. Hutchinson. Tokyo: Japan Antibiotics Research Association.

Pang, C. P., Chakravarti, B., Adlington, R. M., Ting, H. H., White, R. L., Jayatilake, G. S., Baldwin, J. E. \& Abraham, E. P. (1984). Purification of isopenicillin $\mathrm{N}$ synthetase. Biochemical Journal 222, 789-795.

Perlman, R. L., De Combruggle, B. \& Pastan, I. (1969). Cyclic-AMP regulates catabolite and transient repression in E. coli. Nature, London 223, 810812.

RAGAN, C. M. \& VINING, L. C. (1978). Intracellular cyclic adenosine $3^{\prime}, 5^{\prime}$-monophosphate levels and streptomycin production in cultures of Streptomyces griseus. Canadian Journal of Microbiology 24, 1012 1015

Ramos, F. R., Lopez-Nieto, M. J. \& Martín, J. F. (1985). Isopenicillin $\mathrm{N}$ synthetase of Penicillium chrysogenum, an enzyme that converts $\delta(\mathrm{L}-\alpha$-aminoadipyl)-L-cysteinyl-D-valine to isopenicillin N. Antimicrobial Agents and Chemotherapy 27, 380-387.

Revilla, G., Lopez-Nieto, M. J., LuenGo, J. M. \& MARTín, J. F. (1984). Carbon catabolite repression of penicillin biosynthesis by Penicillium chrysogenum. Journal of Antibiotics 37, 781-789.

Romero, J., Liras, P. \& Martín, J. F. (1984). Dissociation of cephamycin and clavulanic acid biosynthesis in Streptomyces clavuligerus. Applied Microbiology and Biotechnology 20, 318-325.

Vadeboncoeur, C. \& TrahaN, L. (1982). Glucose transport in Streptococcus salivarius. Evidence for the presence of a distinct phosphoenol-pyruvate:glucose phosphotransferase system which catalyses the phosphorylation of $\alpha$-methylglucoside. Canadian Journal of Microbiology 28, 190-199.

ZANCA, D. M. \& MARTín, J. F. (1983). Carbon catabolite regulation of the conversion of penicillin into cephalosporin C. Journal of Antibiotics 36, 700708. 